\title{
Surface Process Study for Oil Recovery Using a Thermal Extraction Process
}

\author{
Topical Report
}

\author{
V. K. Sethl \\ R. M. Satchwell \\ L. A. Johnson, Jr.
}

Work Performed Under Cooperative Agreement No.: DE-FC21-86MC1 1076

\author{
For \\ U.S. Department of Energy \\ Office of Fossil Energy \\ Morgantown Energy Technology Center \\ P.O. Box 880 \\ Morgantown, West Virginia 26507-0880 \\ By
Western Research Institute
365 North $9^{\text {th }}$ Street
Laramie, Wyoming 82070
}

June 1994 


\section{DISCLAIMER}

This report was prepared as an account of work sponsored by an agency of the United States Government. Neither the United States Government nor any agency thereof, nor any of their employees, make any warranty, express or implied, or assumes any legal liability or responsibility for the accuracy, completeness, or usefuiness of any information, apparatus, product, or process disclosed, or represents that its use would not infringe privately owned rights. Reference herein to any specific commercial product, process, or service by trade name, trademark, manufacturer, or otherwise does not necessarily constitute or imply its endorsement, recommendation, or favoring by the United States Government or any agency thereof. The views and opinions of authors expressed herein do not necessarily state or reflect those of the United States Government or any agency thereof. 


\section{DISCLAIMER}

Portions of this document may be illegible in electronic image products. Images are produced from the best avaliable original document. 
LIST OF TABLES AND FIGURES $\ldots \ldots \ldots \ldots \ldots \ldots \ldots$ iii

EXECUTIVE SUMMARY $\ldots \ldots \ldots \ldots \ldots \ldots \ldots \ldots \ldots \ldots$ iv

INTRODUCTION $\ldots \ldots \ldots \ldots \ldots \ldots \ldots \ldots \ldots \ldots \ldots \ldots$

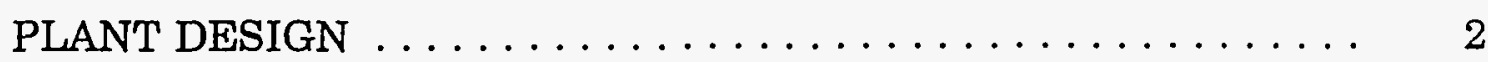

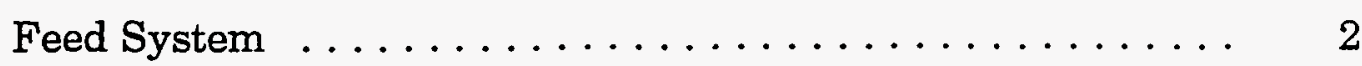

Reactor .......................... 2

Particulate Removal . . . . . . . . . . . . . 4

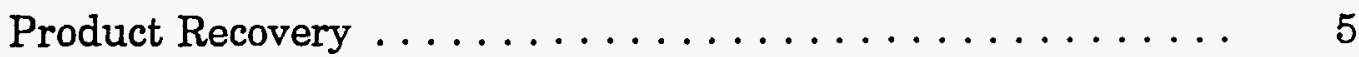

Gas Recycle Loop ................... 6

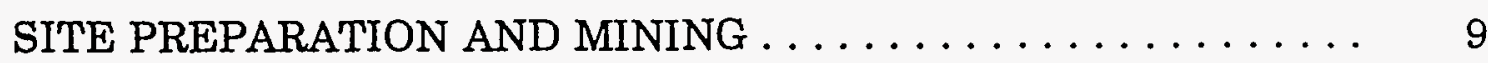

PLANT OPERATIONS $\ldots \ldots \ldots \ldots \ldots \ldots \ldots \ldots \ldots \ldots \ldots \ldots \ldots$

Shakedown, Modifications, and Operation $\ldots \ldots \ldots \ldots \ldots \quad 12$

Start-Up Procedure ................... 15

TEST RESULTS $\ldots \ldots \ldots \ldots \ldots \ldots \ldots \ldots \ldots \ldots \ldots \ldots \ldots \ldots \ldots \ldots$

Feed Quality ....................... 18

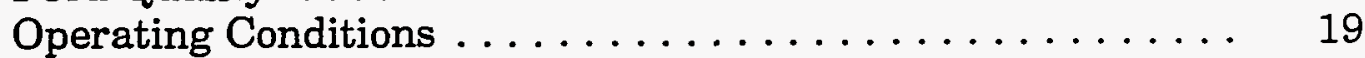

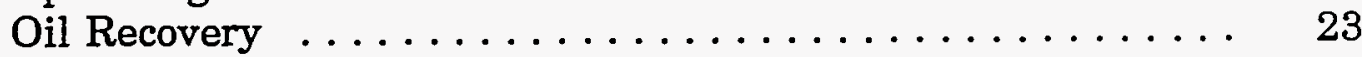

SUMMARY AND CONCLUSIONS $\ldots \ldots \ldots \ldots \ldots \ldots \ldots \ldots 25$

ACKNOWLEDGEMENT $\ldots \ldots \ldots \ldots \ldots \ldots \ldots \ldots \ldots \ldots . \ldots \ldots$

DISCLAIMER $\ldots \ldots \ldots \ldots \ldots \ldots \ldots \ldots \ldots \ldots \ldots \ldots \ldots \ldots \ldots \ldots$

REFERENCES $\ldots \ldots \ldots \ldots \ldots \ldots \ldots \ldots \ldots \ldots \ldots \ldots \ldots \ldots \ldots \ldots \ldots \ldots \ldots$ 


\section{LIST OF TABLES AND FIGURES}

Table

Page

1. Feed Analyses . . . . . . . . . . . . . . . . 19

2. Summary of Test Conditions $\ldots \ldots \ldots \ldots \ldots \ldots \ldots 24$

1. Schematic of the Plant Layout as Assembled at the Sherard Dome ..................... 3

2. Aerial View of the Plant During Assembly $\ldots \ldots \ldots \ldots$

3. Aerial View of the Plant During Assembly $\ldots \ldots \ldots \ldots$

4. Location of Suggested Mining Area, Superimposed on Top of a Map from Chuman and Paine (1988) . . . . . . . 10

5. Schematic Showing the Arrangement of Plugged Bubble Caps 13

6. Schematic of the Plant Layout $\ldots \ldots \ldots \ldots \ldots \ldots \ldots$

7. Temperature Logs for Test Number $1 \ldots \ldots \ldots \ldots$

8. Temperature Logs for Test Number $2 \ldots \ldots \ldots \ldots 20$

9. Temperature Logs for Test Number $3 \ldots \ldots \ldots \ldots 21$

10. Temperature Logs for Test Number $4 \ldots \ldots \ldots \ldots 21$

11. Temperature Logs for Test Number $5 \ldots \ldots \ldots \ldots 22$

12. Temperature Logs for Test Number $6 \ldots \ldots \ldots \ldots 22$

13. Temperature Logs for Test Number $7 \ldots \ldots \ldots \ldots 23$ 


\section{EXECUTIVE SUMMARY}

Recovery and production of oil is an integral part of the State of Wyoming's economy. Geological studies have shown that Wyoming has many minable formations which contain substantial concentrations of oil. Some of the highest concentrations of oil in such occurrences exist in Big Horn, Natrona, Fremont, and Crook Counties. The formations typically consist of unconsolidated or friable sandstone which is unsuited for development by conventional oil recovery techniques. Nevertheless, the rock material acts as a trap for oil, containing millions of barrels per occurrence. At the present time, such resources are undeveloped and do not provide any economic benefits to the State of Wyoming, nor do they enter into the national energy independence equation.

Western Research Institute (WRI) proposed a two phase test program to develop and demonstrate a surface processing scheme for recovering oil from surface and near-surface oil-bearing outcrops. Phase 1 of the test program consisted of bench- and laboratory-scale work to evaluate the viability of existing technologies for surface processing of oil-bearing rock. Phase 1 also included drainage tests to determine if recovery techniques such as horizontal drilling could be applied to the reservoir. Work was also done to identify the optimum processing conditions for these materials, and then based on the economics and other factors such as complexity and scale-up considerations, to define a best candidate for field demonstration. Phase 2 of the program was to evaluate the best candidate process in detail, leading to the design and evaluation of an economically and technically viable process, including a field demonstration at approximately 100 tons per day (tpd) scale. The program was approved as Task 5.21 of the U.S. Department of Energy, Jointly Sponsored Research Program.

Phase 1 of the program consisted of (1) characterization of a preselected target reservoir, (2) bench- and laboratory-scale evaluation of candidate processes, such as hot water and solvent extraction, and thermal processing, using reservoir material, (3) laboratory simulations of the gravity drainage process, (4) process and product evaluation, (5) preliminary design of the scaleup version of the process to field-pilot size. Phase 1 work was completed in early 1993, and a final Phase 1 report has been issued. 
From the results obtained in Phase 1, a fluidized-bed based pilot facility was designed. The main advantages of the selected technology over the screw reactor were the process scale-up considerations and the need to achieve high heating rates and shorter residence times than possible in the screw reactor based system. Fluidized-bed technology also offered an additional advantage in that higher throughput is possible in a relatively small-scale reactor. A reference design of the demonstration plant is presented.

A nominal plant capacity of $100 \mathrm{tpd}$ was used for sizing the equipment. Major subsystems designed were feed preparation, fluidized-bed reactor, particulate removal, product recovery, and gas handling circuits.

The plant components were fabricated at WRI facilities, and the plant was assembled at the Sherard Dome site during August 1993. The project cosponsor, Reneau Energy Inc., La Quinta, California, mined the oil sands for processing. The plant was operated for 27 days including a shakedown period.

Several problems were experienced. The major issue pertained to the lower than expected oil content of the feed. This in turn had an adverse impact on the performance of product recovery components. Nevertheless, the plant processed sufficient quantities of the low grade feed to develop an adequate appraisal of plant performance. 


\section{INTRODUCTION}

Geological studies have shown that there are many surface or nearsurface deposits in the United States that contain large quantities of petroleum. In the State of Wyoming, a high concentration of such deposits exists in the Wind River, Big Horn, and Powder River Basins. These shallow deposits typically occur as unconsolidated or friable formations that contain millions of barrels of oil. Conventional petroleum production techniques have been attempted in many of these deposits with little or no economic success. In an attempt to improve the production economics, the Western Research Institute (WRI) was solicited to develop a technique for the recovery of oil from these deposits. Western Research Institute, with support from the Economic and Community Development Division of the State of Wyoming, and as a part of the WRI/U.S. Department of Energy, Jointly Sponsored Research program, proposed to develop, test, and demonstrate a viable and economical technology for the recovery of oil using mining and surface recovery processes. Reneau Energy, Inc. of La Quinta, California, agreed to participate in the project in providing a test site and mined materials.

The goal of the proposed project to be completed in two phases, was to develop existing energy resources which are not presently being utilized. Phase 1 of the project, consisting of six specific tasks, was conducted to evaluate the suitability of various surface processing schemes. Phase 1 also included gravity drainage tests to determine if recovery techniques such as horizontal drilling could be applied.

Phase 1 work was completed, and a final report was prepared and submitted to the funding agencies (Satchwell et al. 1993). Based on the results obtained in Phase 1 of the project, fluidized-bed based thermal recovery appeared to be a viable option. A 100 tons per day (tpd) pilot plant was designed, constructed, and operated in the field. This report describes the results and experiences of the Phase 2 testing. 


\section{PLANT DESIGN}

A schematic layout of the pilot facility conceived for field demonstration is given in Figure 1. The design basis for the facility was to process nominally 100 tpd of oil sand. A description of the pilot facility is given in the following sections. Individual sibsystems are described, and whenever possible procurement specifications are listed.

\section{Feed System}

Because of the consistency of the mined material used in the laboratoryand bench-scale testing, crushing or grinding of the mined material was deemed unnecessary. Nevertheless, the feed system design provided a small crusher capable of breaking large lumps of mined material into a manageable sized feed. The feed system also had provisions for screening the material to 1 -inch top size. Screened material was then conveyed into a surge hopper. Surge hopper capacity was designed to be about 20 tons of oil sand or approximately 4 hours of continuous operation at maximum rated capacity of the plant.

Oil sand from the surge hopper was fed into the fluidized-bed reactor via a twin screw capable of feeding the material at a nominal feed rate of about 5 tons per hour (tph).

\section{$\underline{\text { Reactor }}$}

Design considerations for sizing the reactor were based on bench-scale reactor tests. Residence time, bed height and proposed feed rate and concomitant thermal input requirements were used to define the design parameters, as follows:

$\begin{array}{ll}\text { Fluidizing Velocity } & \text { up to } 4 \mathrm{f} / \mathrm{s}(1.2 \mathrm{~m} / \mathrm{s}) \\ \text { Feed Rate } & 5 \mathrm{tph}(4536 \mathrm{~kg} / \mathrm{hr}) \\ \text { Bed Height } & 18 \text { and } 36 \text { inches }(0.45 \text { and } 0.90 \mathrm{~m}) \\ \text { Temperature } & 750-850^{\circ} \mathrm{F}\left(399-454^{\circ} \mathrm{C}\right) \\ \text { Bed Area } & 15 \mathrm{ft}^{2}\left(1.4 \mathrm{~m}^{2}\right)\end{array}$




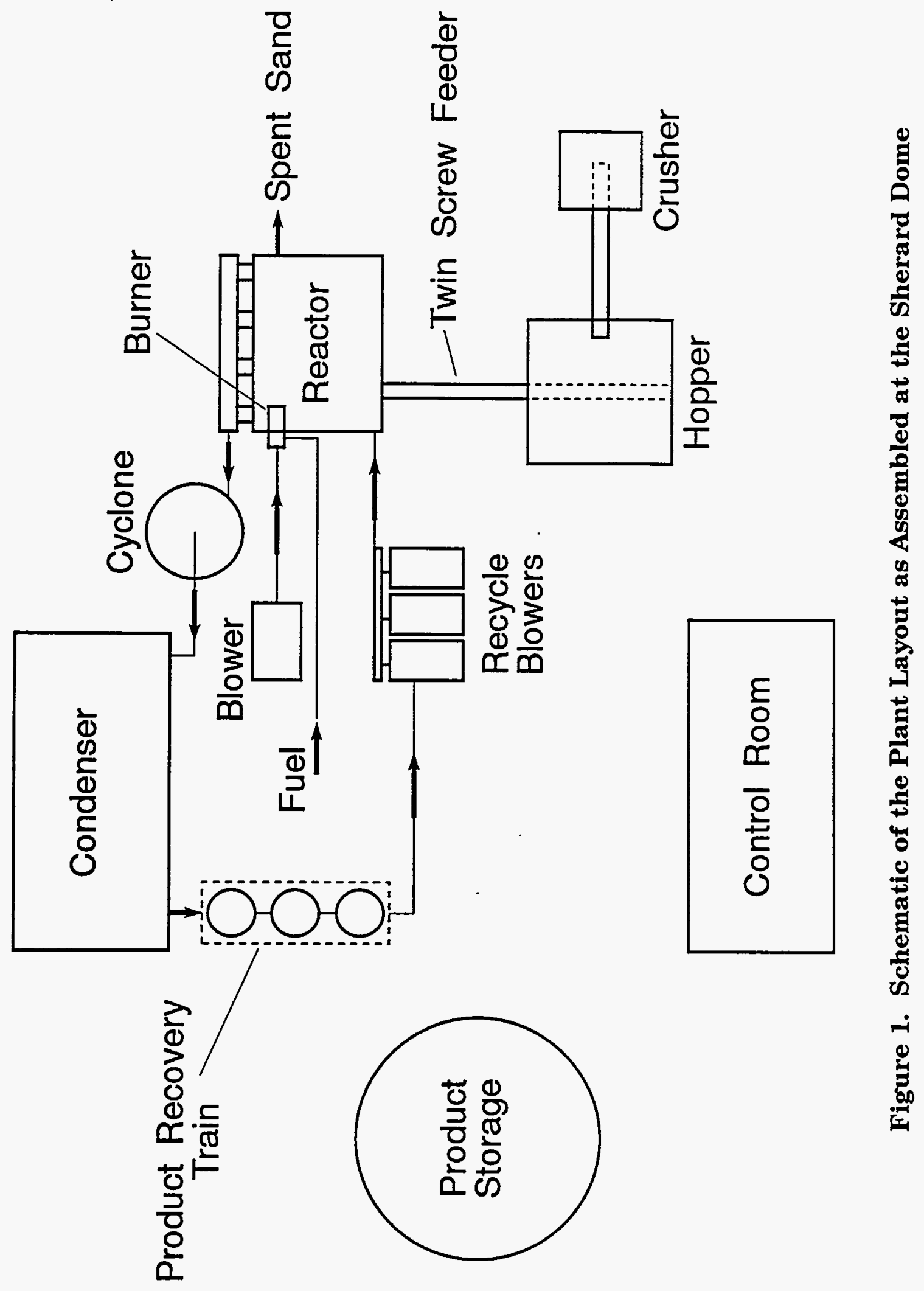


Windbox design involved operation at temperatures up to $2100^{\circ} \mathrm{F}$ $\left(1149^{\circ} \mathrm{C}\right)$. A refractory lined, $7 \times 5 \mathrm{ft}(2.13 \times 1.52 \mathrm{~m})$ box was envisioned. Nonsquare box dimensions were selected to prevent propane burner flame impingement onto the opposing refractory wall. The height of the box was about $4 \mathrm{ft}(1.22 \mathrm{~m})$. A $5 \mathrm{MMBtu} / \mathrm{hr}$ propane-fired burner was installed on one of the shorter sides of the windbox. Combustion air for the burner was provided by blowers capable of delivering up to $4000 \mathrm{lb} / \mathrm{hr}(1814 \mathrm{~kg} / \mathrm{hr})$ of air. The gas temperature in the windbox was maintained at the desired value by mixing the combustion gases with recycle gas. Typically, half of the total fluidizing gas flow through the reactor was expected to be from the recycle gas stream. Note that the actual amount of recycle is related to the bed operating temperature, fluidizing-gas temperature, bed inventory, feed quality, and the feed rate.

The distributor plate was of the bubble cap type, a design commonly used in fluidized-bed coal combustors. To keep the plant design simple, an uncooled distributor design was selected. This then dictated that a high strength, high chromium containing, oxidation resistant material be used for the distributor plate. An uncooled, 0.5-inch $(12.7 \mathrm{~mm})$ thick, type 310 stainless steel plate was used. Type 304 stainless steel bubble caps were made from 1inch schedule 80 nipples attached to the 310 stainless steel distributor plate by welding.

The reactor itself was a refractory-lined box, $5.5 \mathrm{ft}$-long by $3.5 \mathrm{ft}$-wide $(1.68 \mathrm{~m}$ by $1.07 \mathrm{~m})$. The height of the reactor was about $7 \mathrm{ft}(2.13 \mathrm{~m})$. Several instrumentation ports were incorporated in the design of the reactor.

\section{Particulate Removal}

Bench-scale tests conducted in Phase 1 had shown that even at relatively low fluidizing velocities, particulate removal devices were needed to remove the elutriated bed material from the product vapors and gases. In order to minimize the thermal losses, the primary particulate cleanup device, a set of four small cyclones in parallel, was installed inside the reactor. These cyclones were anchored to one side of the reactor with the inlets located in the freeboard area. The cyclones discharged the collected solids through a set of inclined tubes, one for each cyclone. Cleaned gases from the four cyclones were manifolded into a 10-inch externally insulated pipe. 
In addition to the primary cyclones, a secondary, high efficiency cyclone was incorporated in the particulate removal train, external to the reactor. Based on the bench-scale tests, particulate loading at the inlet of the primary cyclones was expected to be about 10,000 parts per million by weight (ppmw). The secondary cyclone was designed with the assumption that primary cyclones will operate at about $90 \%$ collection efficiency. The secondary cyclone was an externally insulated unit, constructed from type 304 stainless steel.

\title{
Product Recovery
}

Particulate free gases passed through an air-cooled condenser. Design specifications for the condenser were developed and refined by working closely with equipment manufacturers. Based on the plant capacity and the feed analyses, condenser design specifications developed were:

\author{
Thermal Load $\quad 2.5 \mathrm{MMBtu} / \mathrm{hr}$ \\ Inlet Temperature $850^{\circ} \mathrm{F}\left(454^{\circ} \mathrm{C}\right)$ \\ Outlet Temperature $180^{\circ} \mathrm{F}\left(82^{\circ} \mathrm{C}\right)$ \\ Bottoms \\ $850 \mathrm{lb} / \mathrm{hr}(386 \mathrm{~kg} / \mathrm{hr})$ oil \\ Overhead \\ $9000 \mathrm{lb} / \mathrm{hr}(4082 \mathrm{~kg} / \mathrm{hr})$ combustion gases and steam
}

Product recovery and condensate collection was through liquid level controlled, pumped knockouts located at the outlet of the condenser. Standard oil field equipment was selected for this service. Since a portion of the gases exiting the condenser needed to be recycled, an aftercooler was included in the design to further cool the gases and thus allow the use of conventional blowers in the recycle loop.

Condensate collected in the knockouts was designed to be sent to a 400 bbl storage/separator tank. The separator tank was equipped with provisions for pumping the oil to another storage tank, and for pumping the water to a spray for cooling the spent sand. 


\section{Gas Recycle Loop}

Gas recirculation loop design included recycle blowers and a series of manual valves to control the flow rate and pressure in various parts of the system. A portion of the stream was diverted to the windbox of the reactor, while the rest was sent to a flare. Ratio of the recycle stream to the flare stream was controlled by using a choke in the flare circuit.

All major components were assembled at WRI facilities and taken through hot tests to refine control strategies, data logging, and exact plant layout and components siting. No solids were present in the reactor during these operations. Several complications were discovered and remedied. The distributor plate buckled and developed cracks at a weld joint leading to air leaks at the flanged joint between the windbox and the reactor. The weld was repaired and the distributor plate was flattened. Additional bolt holes were drilled to seal the areas where air leaks were persistent.

The plant was then dismantled into sections suitable for highway transport, and shipped to the Sherard site. Over a 1 week period, all components were reassembled at the test site. Aerial photographs of the assembled plant at the test site are presented in Figures 2 and 3. 


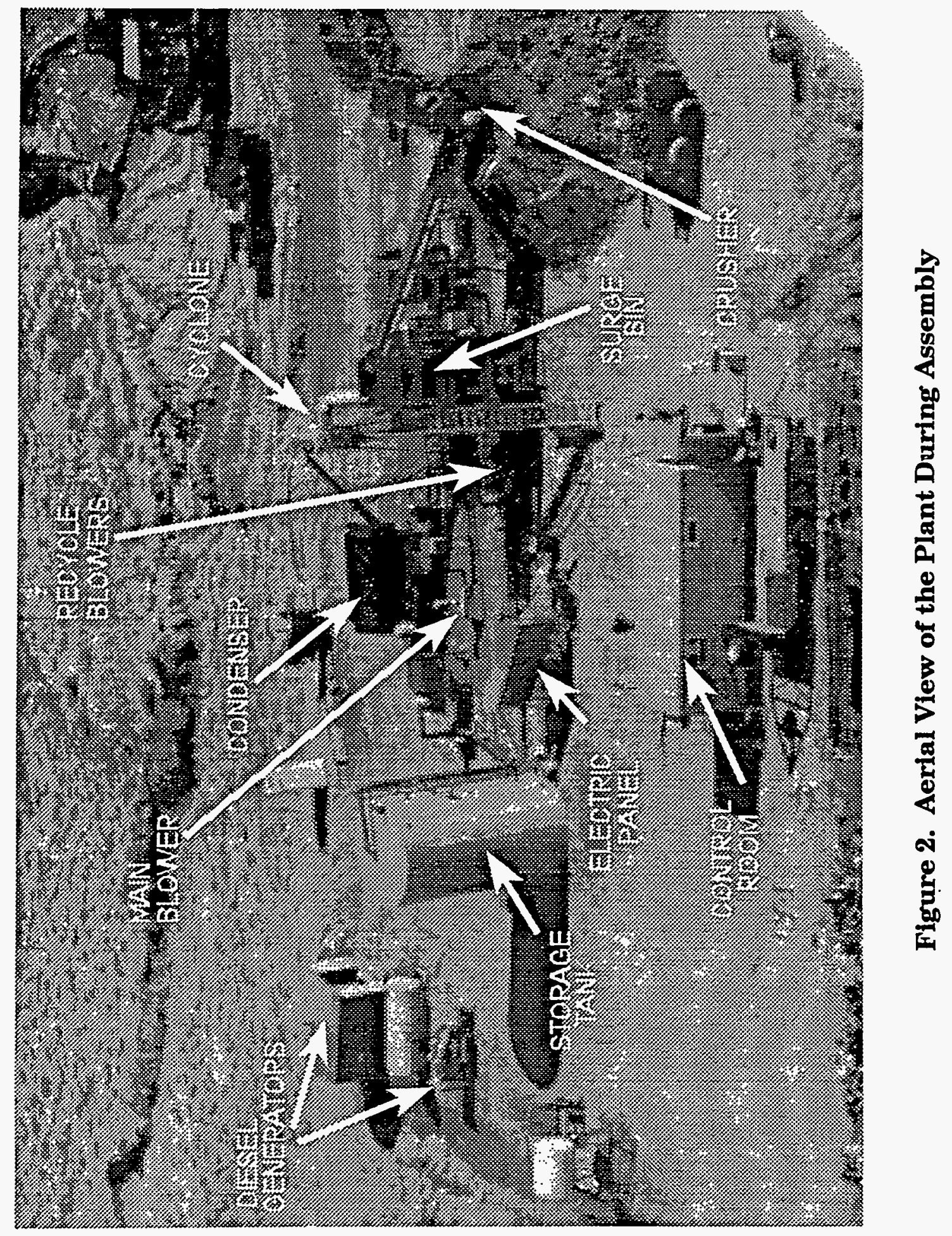




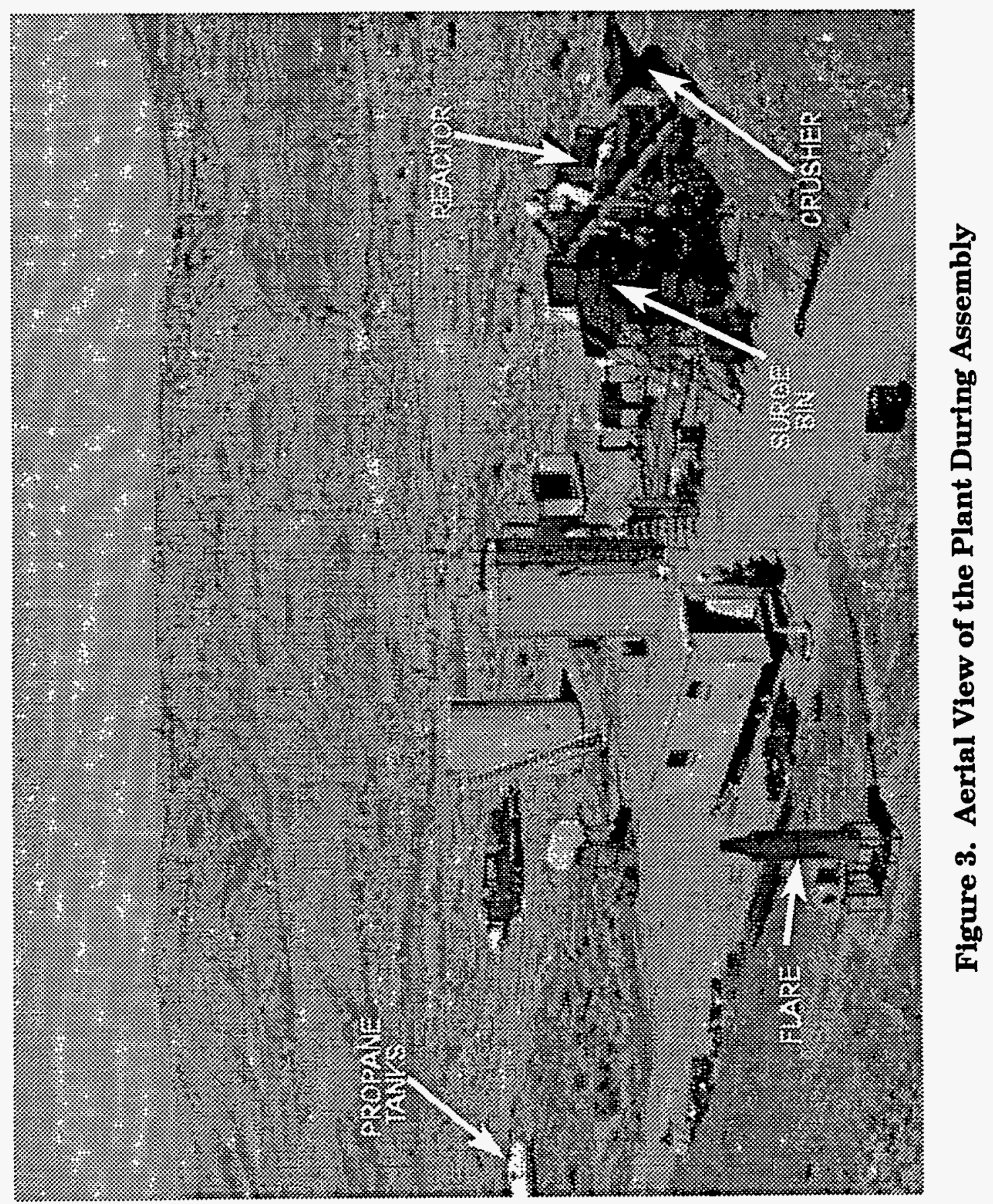




\section{SITE PREPARATION AND MINING}

A geological appraisal of the Sherard Dome was conducted under Phase

1. Major findings of the work were:

1. A general trend exists at the reservoir such that sandstones structurally higher on Sherard Dome have the highest oil saturation. However, there are no clearly defined oil-water contacts. In fact, there appeared to be many levels of zero oil saturation. The most likely reason for this situation is thought to be the presence of numerous fine layers in the Third Frontier oil sand, each with its own base of the oil zone.

2. The individual oil sand layers at Sherard Dome are not in equilibrium with each other. The sand layers are separated structurally, due to faults along the margins of the dome, and also separated stratigraphically due to the laminated nature of the marine sandstone.

3. Oil mining should be initially confined to above $4,535 \mathrm{ft}$ above sea level to maximize the amount of oil recovered per barrel of water produced. Deeper mining would yield more oil, but the small incremental fraction of oil will be accompanied by a high increase in water cut.

Based on the geological work, an area for viable oil production was identified. Figure 4 shows the location of the mining area for the Third Frontier oil sand suggested by WRI's Phase 1 work. As stated in the Phase 1 report, this area was much smaller than the region proposed earlier (Chuman and Paine 1988) because of the presence of numerous faults and complex geology surrounding Sherard Dome. It was suggested that only the southern portion of the dome should be mined, away from complications of fault zones and steeply dipping sands. The large square in Figure 4 covers 34.3 acres $\left(\sim 140,000 \mathrm{~m}^{2}\right)$. Average porosity of the Third Frontier in this area is 0.26 , with an average oil saturation of 0.37 . Thickness of the oil-bearing sand being 45 $\mathrm{ft}(13.7 \mathrm{~m})$ on average, yielded an estimated oil in place of $1.13 \mathrm{MMbbl}$.

A smaller subset of the large 34.3-acre area is indicated by a 9.4-acre $\left(\sim 38,297-\mathrm{m}^{2}\right)$ triangular region shown in Figure 4. WRI's geological evaluation had shown that this area has less overburden (approximately $15 \mathrm{ft}[4.57 \mathrm{~m}]$ compared to nearly $30 \mathrm{ft}$ [9.14 $\mathrm{m}$ ] or more outside of the triangle), and a better 


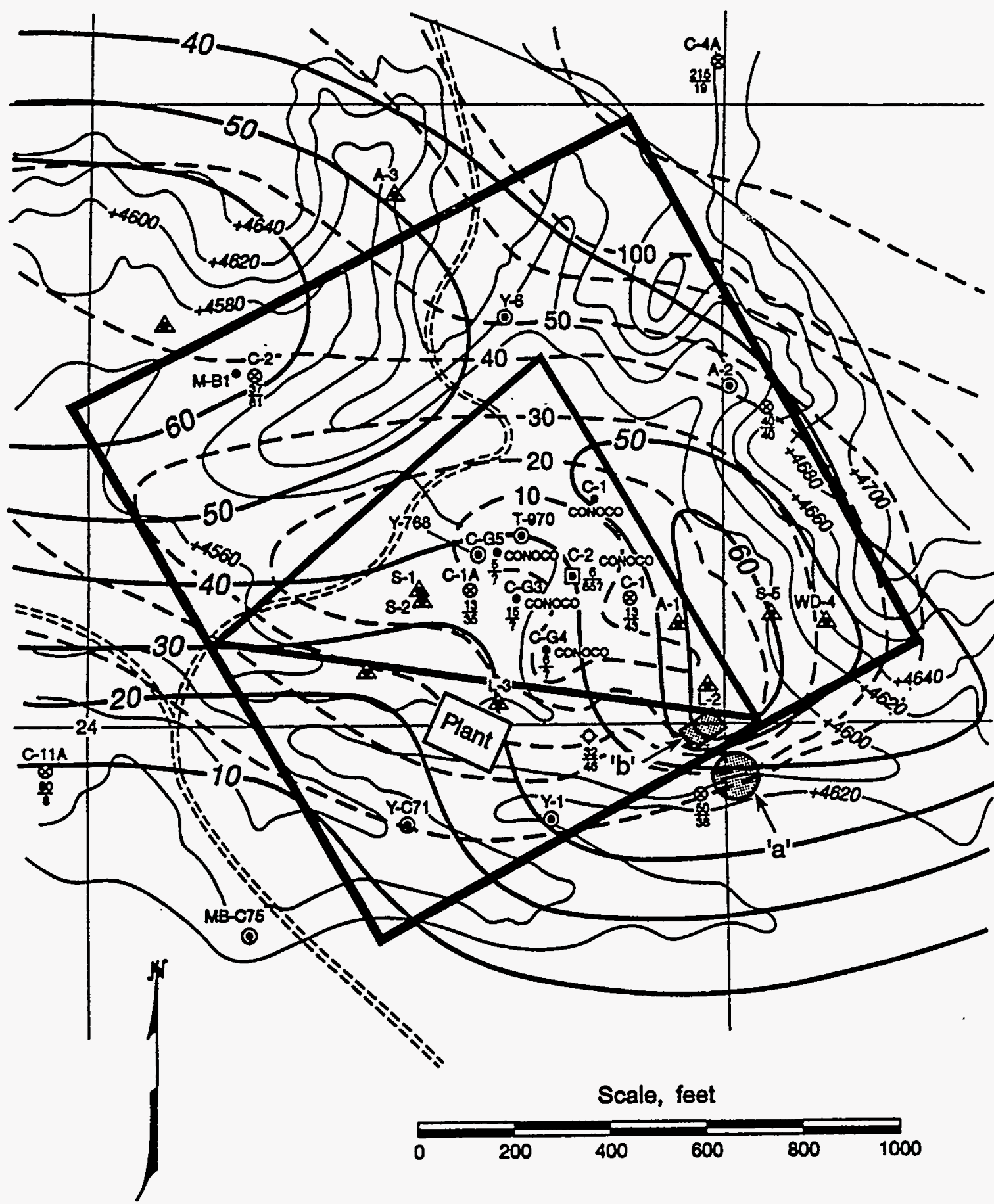

Figure 4. Location of Suggested Mining Area, Superimposed on Top of a Map from Chuman and Paine (1988). Triangular area contains most optimal conditions for oil extraction. Larger box is an area of reasonable potential which avoids surrounding fault zones. Shaded circle labeled as "a" and shaded rectangle labeled as " $\mathrm{b}$ " represent mining locations for the demonstration project. 
proven oil resource. Therefore it was suggested that the pilot project should probably be undertaken in this smaller area before proceeding to full-scale mining. This triangular area was estimated to contain approximately 316,000 $\mathrm{bbl}$ of oil within $60 \mathrm{ft}(18.3 \mathrm{~m})$ of the surface.

Site preparation and mining of the resource for testing were the responsibility of the project cosponsor, Reneau Energy, Inc. Approximately 2 months prior to the construction of the pilot plant at the test site, WRI staff visited the site and met with the cosponsors and their mining subcontractors. Space requirements for the plant, and the approximate plant layout were marked for grading. Locations for feed storage and interim storage of spent material were identified. Need for some grading and leveling of the access road to the site for heavy truck loads was identified.

The area initially mined by the cosponsor is displayed in Figure 4 by a shaded circle. Please note that the area is at the boundary of the 34.3 acre area identified by WRI's geological study as being best suited for surface mining. After nearly $25 \mathrm{ft}(7.6 \mathrm{~m})$ of excavation some oil-water saturated sand was encountered. When WRI personnel arrived at the site, this material had been mined and stockpiled for use during plant shakedown. The stockpile also contained overburden, in that substantial amounts of hard rocks were present. Although there were fist-size pieces of the resource that were dripping oil, overall the stockpile appeared to be relatively lean compared to the material used for bench-scale testing.

As described later in this report, shakedown testing with the mined resource indicated that the plant was not capable of handling the mined material for two reasons: (1) crushing and feed equipment was not capable of handling large chunks of hard rock, and (2) relatively lean feedstock meant little oil production. The later caused WRI staff to assume that the product recovery system was functioning improperly, while in fact little oil was being produced. Meanwhile, the cosponsor, Reneau Energy, Inc. was informed that the area of mining was outside of the zone recommended by WRI. The mining operation moved to the north by about $75 \mathrm{ft}(\sim 23 \mathrm{~m})$, however as shown in Figure 4 by a shaded rectangle, it was still not in the area recommended for pilot plant operations. Some testing was done using this material. Subsequent analysis of this material described later in the report showed that the oil content of the mined material was still at best marginal. 


\section{PLANT OPERATIONS}

\section{Shakedown, Modifications, and Operation}

Plant components were assembled at the site during a 1 week period ending on August 25, 1993. The burner was ignited on August 26, 1993. Several minor problems were discovered. Problems included, excessively high pressure drop across the product recovery train, relatively low temperature in the windbox, presence of oversized rocks which did not contain hydrocarbons in the feed, and lack of fluidization in the bed.

The high pressure drop was traced to the aftercooler and the secondary knockout pot in the product recovery train and the components were removed from the circuit. During system checkout at the WRI premises, the aftercooler was not installed in the loop, and hence, the excessive pressure drop in the component was quite unexpected. New product collection and recovery components, a series of knockout pots and associated piping and plumbing fixtures, were procured and installed in the product recovery train. With hindsight some of this pressure drop was also caused by the lack of condensibles in the product stream because of the lower than expected oil content of the resource.

Low temperatures in the windbox were caused by restricted propane flow. The fuel supplier was contacted, and a fuel flow regulator with a larger hole was installed at the propane tanks to provide adequate propane flow rates. The propane flow rate at night time when ambient temperature decreased, still showed a substantial drop, noticeable as a drop in the windbox temperature.

Lack of fluidization in the bed was related to the inadequacy of the blower capacity at the higher than expected back pressures. Blower arrangements were modified by swapping blowers from the primary air circuit to the recycle circuit.

With aforementioned modifications, a windbox temperature of $1300^{\circ} \mathrm{F}$ $\left(704^{\circ} \mathrm{C}\right.$ ) was achieved on August 30,1993. Air flow under these conditions was not sufficient to fluidize the bed. Visual inspection showed that isolated local areas in the bed were close to fluidization. In order to increase the superficial gas velocity, the bed area was reduced by installing a layer of fire brick over 
the lower 12 inches $(0.3 \mathrm{~m})$ of the reactor walls. This produced a net reduction in the bed area of about $20 \%$. Tests showed that this reduction was not enough and further decrease in the bed area was needed. This was achieved by blocking 24 out of 60 bubble caps in a pattern such that two diagonally opposite corners of the bed were made inoperative (Figure 5).

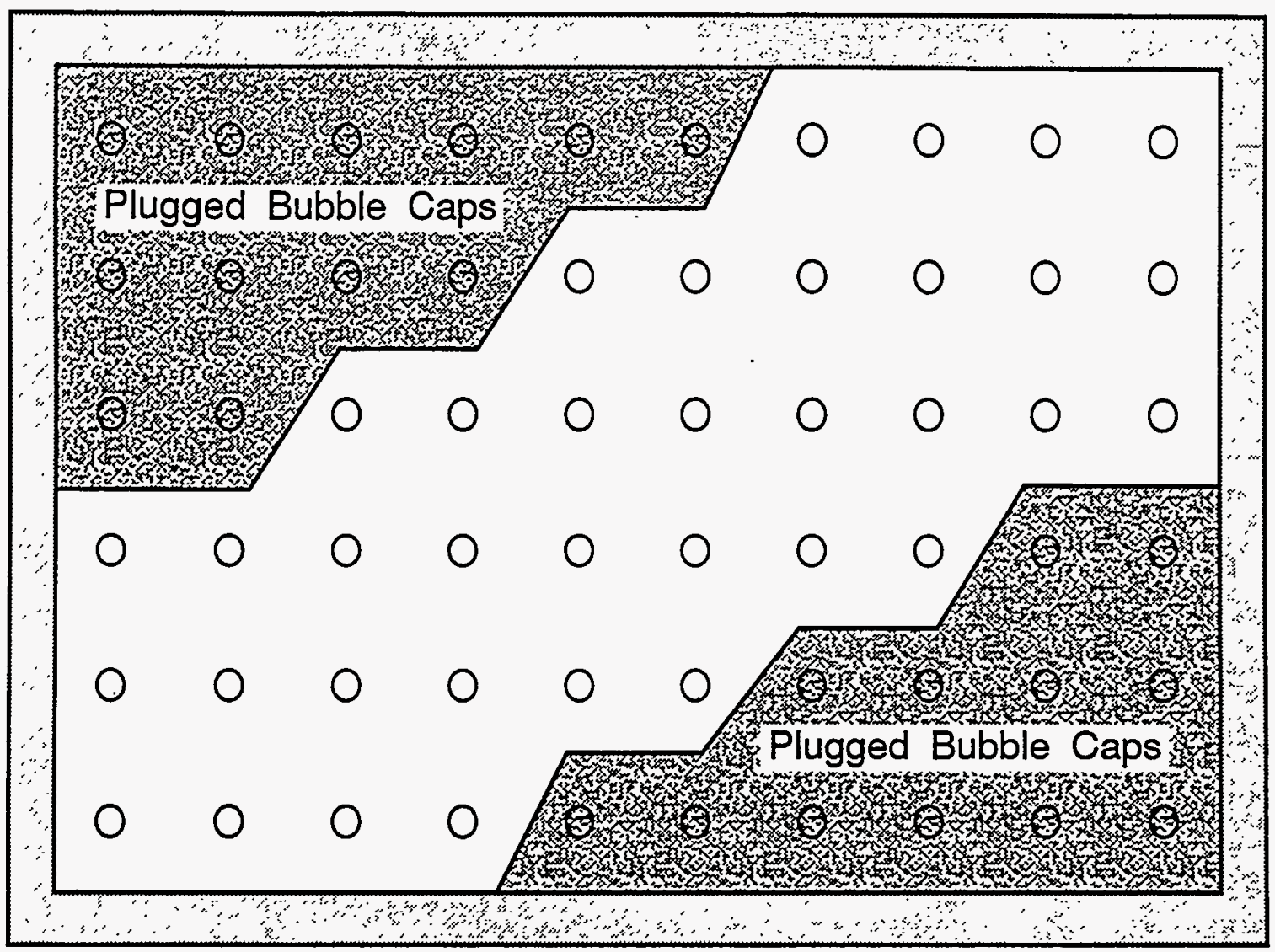

Figure 5. Schematic Showing the Arrangement of Plugged Bubble Caps

Higher than expected back pressure in the system was also traced to the size of the flare line. The flare located about $100 \mathrm{ft}(30.5 \mathrm{~m})$ away from the plant was fed by a 1.5-inch diameter pipe. Because of the high pressure drop through this line, the overall system pressure increased with time, which in turn adversely impacted the performance of the blowers and that of the propane burner. The size of the line feeding the flare was increased to 3 inches in diameter. 
The feed preparation system was upgraded by adjusting the crusher, and by installing a 1 -inch screen at the surge bin. This arrangement ensured that oversize material was discarded, preventing any damage to the feed screws. However, it did not prevent the ingestion of "inert" material of up to 1-inch top size, into the reactor.

After these modifications were completed, start-up attempts showed that the $400 \mathrm{bbl}$ tank installed in the product recovery train could not withstand the suction created by the recycle blowers. The tank was removed from the product recovery loop and replaced with a smaller, sturdier tank.

The plant was fired at 4:30 p.m. on September 10, 1993. After a 2 hour warm-up period the feed was started. Feed was continued for about 2 hours, and then the system was shutdown for visual inspection of the bed. After a 15minute cool down, the bed was examined through an 8-inch inspection port. No pileup of feed material was evident at or near the screw feed port. The plant was restarted at 10:15 p.m., and feed was initiated at 11:07 p.m. The plant operated until 8:30 a.m. on September 12, 1993, at which time the recycle blowers began making loud "clanging" noise. The run was terminated to inspect the blowers.

Examination of the blowers showed that substantial quantities of water and some oil were present in the recycle line. The noise presumably was caused by the ingestion of water into the blowers. The recycle line was cleaned, and the blowers were serviced to remove all water and other deposits from the blower vanes and housing.

The plant was restarted at 3:10 p.m. on September 12, 1993 and operated near the maximum feed rate until 1:45 a.m. on September 13, 1993. During this period the bed temperature was controlled at the $835-850^{\circ} \mathrm{F}(446$ $-454^{\circ} \mathrm{C}$ ) range by changing the feed rate as appropriate. The shutdown was caused by inadequate propane flow. Propane flow during the night time dropped as the ambient temperature dropped to about $50^{\circ} \mathrm{F}\left(10^{\circ} \mathrm{C}\right)$.

The plant was readied for start-up after installing a vaporizer in the propane line. After the burner was ignited, it was discovered that one of the 
recycle blowers was seized up. As the blower was being worked on, the diesel generators began to fail. The generator supplier was contacted, while attempts were made to fire the plant with the remaining blowers. Periodic failure of the generators lasted through the night of September 14, 1993. The generators were serviced on September 15, 1993. The failures were caused by fuel line pluggage. The service representative also noted that one of the generators was in imminent danger of losing its fan as the hub had almost worn out. Since replacement parts were not readily available, it was decided that the plant should be operated for a day while the parts are procured and then to attempt a replacement. The generator lost its fan 2 hours into the plant start-up and the run had to be aborted until the generator parts could be replaced.

The pilot plant was again started at 7:30 p.m. on September 15, 1993 and operated on a semi-continuous basis until the morning of September 22, 1993. Several test conditions were used during this period. Results are described in the next section. The plant was allowed to cool down and was dismantled. Plant components were shipped back to WRI facilities on September 25, 1993.

\section{Start-Up Procedure}

Because of equipment limitations and feed quality related issues discovered during shakedown tests, the start-up procedure was modified. Originally it was planned that the plant would operate with relatively little pressure drop, and the large $400 \mathrm{bbl}$ product recovery tank would be in the process loop: However, the product recovery loop was modified, and hence, necessitated a change in the plant start-up procedures and in steady-state plant operations.

The start-up procedure employed is described below. Various components are identified in Figure 6.

1. Start data acquisition system, and confirm that all sensors are being logged. 
2. Check status of various valve positions and components, as follows:

Cyclone solid discharge valves

Flare valve (1)

Main valve (2)

$S$ Blower intake valve (3)

Recycle inlet valve (4)

$\mathrm{W}$ and $\mathrm{E}$ Blower by-pass valve

Product pumps (5)

Condenser Fan

Flare pilot

Propane supply

Main air/fuel ratio valve (6)
Open

Open

Closed

Open

Open

Closed

On

On

On

On

Closed

3. Start S, W, and E (recycle) blowers.

4. Open air/fuel ratio valve (6).

5. Start N (main) blower.

6. Close cyclone solid discharge valves.

7. Throttle flare valve (1) until pressure in the reactor is $\sim 2$ psig.

8. Ignite the burner pilot.

9. Open main propane valve, and wait for the desired windbox and bed temperature to be achieved. (The air/fuel ratio valve had been adjusted to maintain slightly fuel-rich conditions in the bed.)

10. Start feed when bed at desired temperature.

11. Control bed temperature by varying feed rate. 


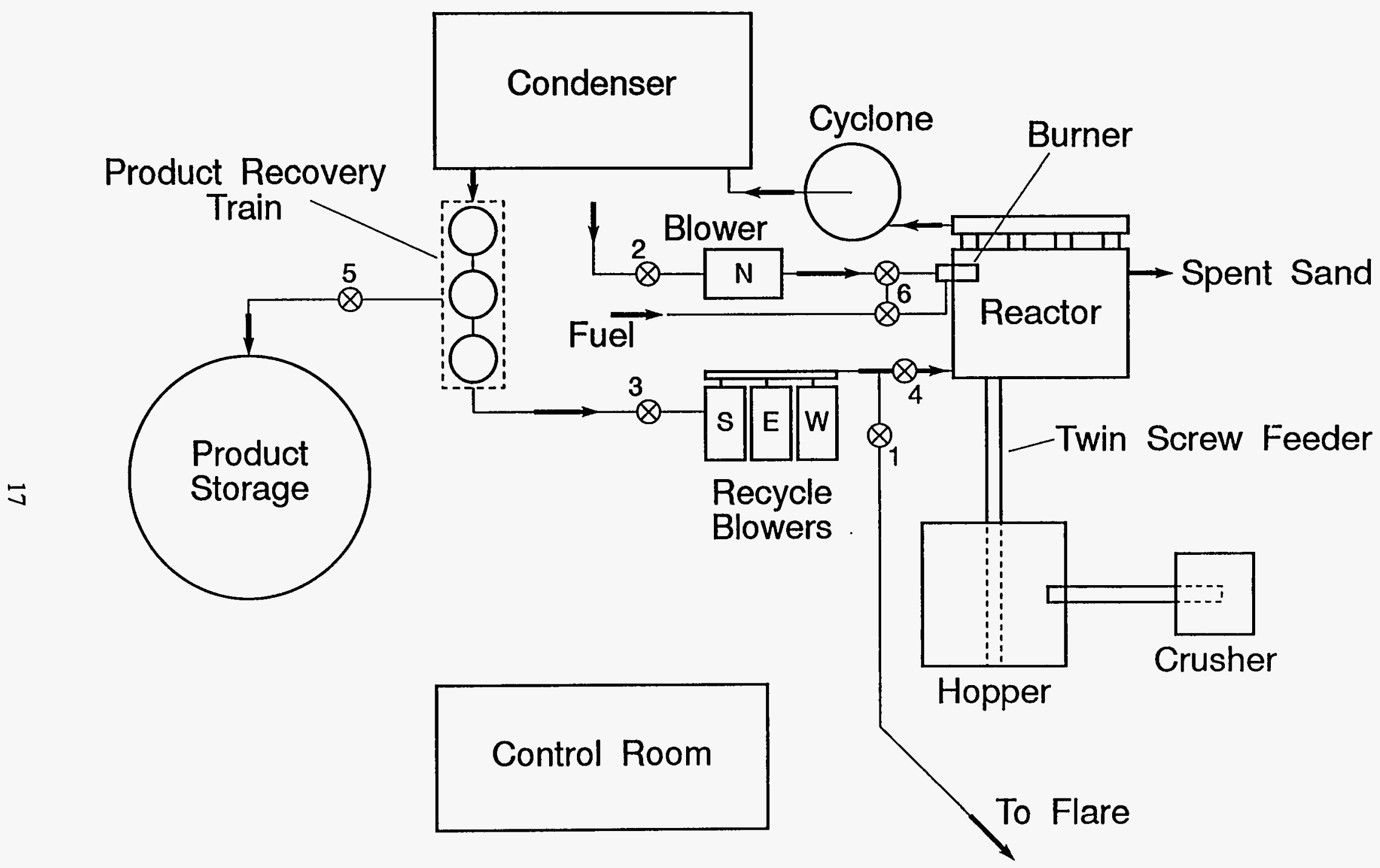

Figure 6. Schematic of the Plant Layout 


\section{TEST RESULTS}

\section{Feed Quality}

Several samples of feed material were collected. The samples were analyzed using a standard WRI procedure, WRI-204, a variant of the conventional Soxhlet extraction procedure combined with azeotropic distillation to remove water and organics from the sample. For the process, 120 to 140 grams of accurately weighed sample is placed in a thimble. The thimble is then inserted into the extractor and the apparatus is assembled. The difference between this procedure and conventional Soxhlet extractions is that a Dean-Stark trap is inserted between the extractor and the condenser. The toluene is allowed to reflux through the extractor for 12 hours. The extractor is allowed to cool, and the water is drained from the Dean-Stark trap into a tared container and weighed. The toluene solution containing the extracted organic component is distilled under vacuum to remove the toluene until a constant weight is achieved. The weight of the organic component and the extracted mineral matter are determined. The weight data of the sample before extraction and the data for the three products are used to determine a mass balance closure around the extraction. The organic saturation is calculated as the weight percentage of the organic in the contaminated soil. Duplicate and blank analyses are performed once in every ten samples analyzed by the method.

Results of the analyses of various samples are compiled in Table 1. From the data displayed in the table, it is quite evident that the feed quality varied substantially. During the shakedown period, material was mined from a location which was situated well outside of the area recommended by WRI. This is identified in Table 1 as location " $a$ ". The oil content of the feed was about $1.8 \mathrm{wt} \%$ (Feed Samples 1 and 3 in Table 1). Oil content of mined material which was visibly oil-rich during this period, was about 3.0 wt \% (Feed Samples 2 and 4 in Table 1). As stated earlier in this report, the mining location was moved north by approximately $75 \mathrm{ft}(23 \mathrm{~m})$. Material used for subsequent plant operations was from the latter location, identified as location " $b$ " in Table 1. Analyses of grab samples taken during the plant operations are listed in Table 1 as Feed Samples 5 - 11. These samples were taken during steady-state plant operations at predetermined conditions. As the data indicate, the feed, even from location "b" was quite variable (1.5 - $10.4 \mathrm{wt} \%$ oil), and often marginal ( $<10 \mathrm{wt} \%)$ in its oil content. 
Table 1. Feed Analyses

\begin{tabular}{ccccc}
\hline $\begin{array}{c}\text { Feed } \\
\text { Sample }\end{array}$ & Date (Test No.) & $\begin{array}{c}\text { Mining } \\
\text { Location }\end{array}$ & $\begin{array}{c}\text { Water } \\
(\mathbf{w t} \%)\end{array}$ & $\begin{array}{c}\text { Oil } \\
\text { (wt \%) }\end{array}$ \\
\hline 1 & $9-10-93$ (Shakedown) & a & 5.83 & 1.87 \\
2 & $9-10-93^{*}$ (Shakedown) & a & 6.05 & 3.21 \\
3 & $9-12-93$ (Shakedown) & a & 2.89 & 1.89 \\
4 & $9-12-93^{*}$ (Shakedown) & a & 1.70 & 2.95 \\
5 & $9-15-93$ (Test 1) & b & 1.86 & 4.67 \\
6 & $9-17-93$ (Test 2) & b & 9.09 & 1.51 \\
7 & $9-20-93$ (Test 3) & b & 4.17 & 5.02 \\
8 & $9-20-93$ (Test 4) & b & 3.69 & 10.39 \\
9 & $9-21-93$ (Test 5) & b & 3.45 & 6.97 \\
10 & $9-21-93$ (Test 6) & b & 1.37 & 7.71 \\
11 & $9-22-93$ (Test 7) & b & 7.09 & 3.12 \\
\hline
\end{tabular}

* These analyses reflect the oil and water content of visibly rich material and hence reflect the highest oil content of the mined material.

\section{Operating Conditions}

During the September $15-22,1993$ period, seven test runs were made at various bed and windbox temperatures. Figures $7-13$ display the steadystate temperature logs prior to sample collection for these tests. Because of a highly variable nature of the feed, bed temperature control (performed manually by varying the speed of feed screws) was quite tedious. Nevertheless, as indicated by the data displayed in the figures, reasonably good steady-state operations were indeed achieved. 


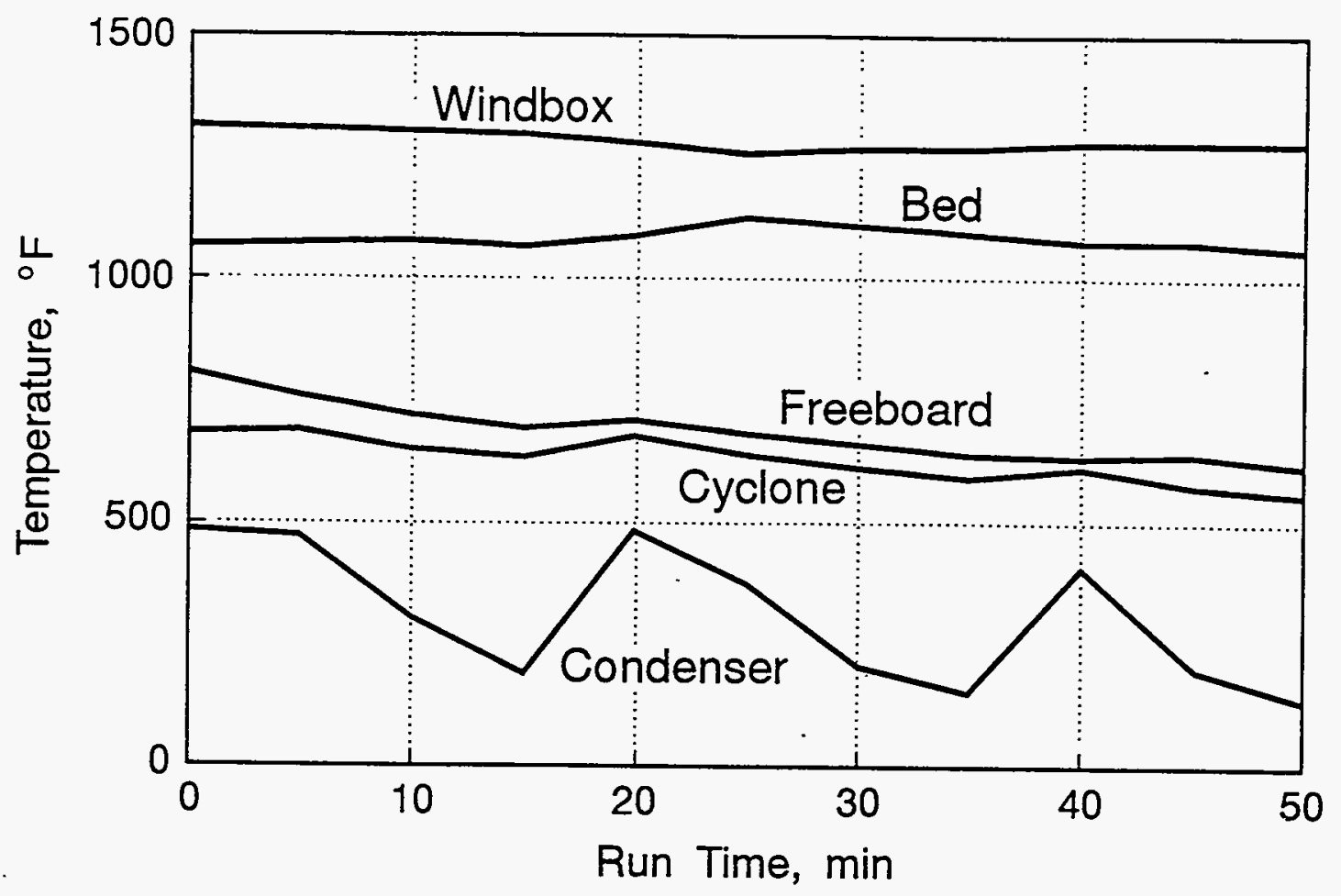

Figure 7. Temperature Logs for Test Number 1

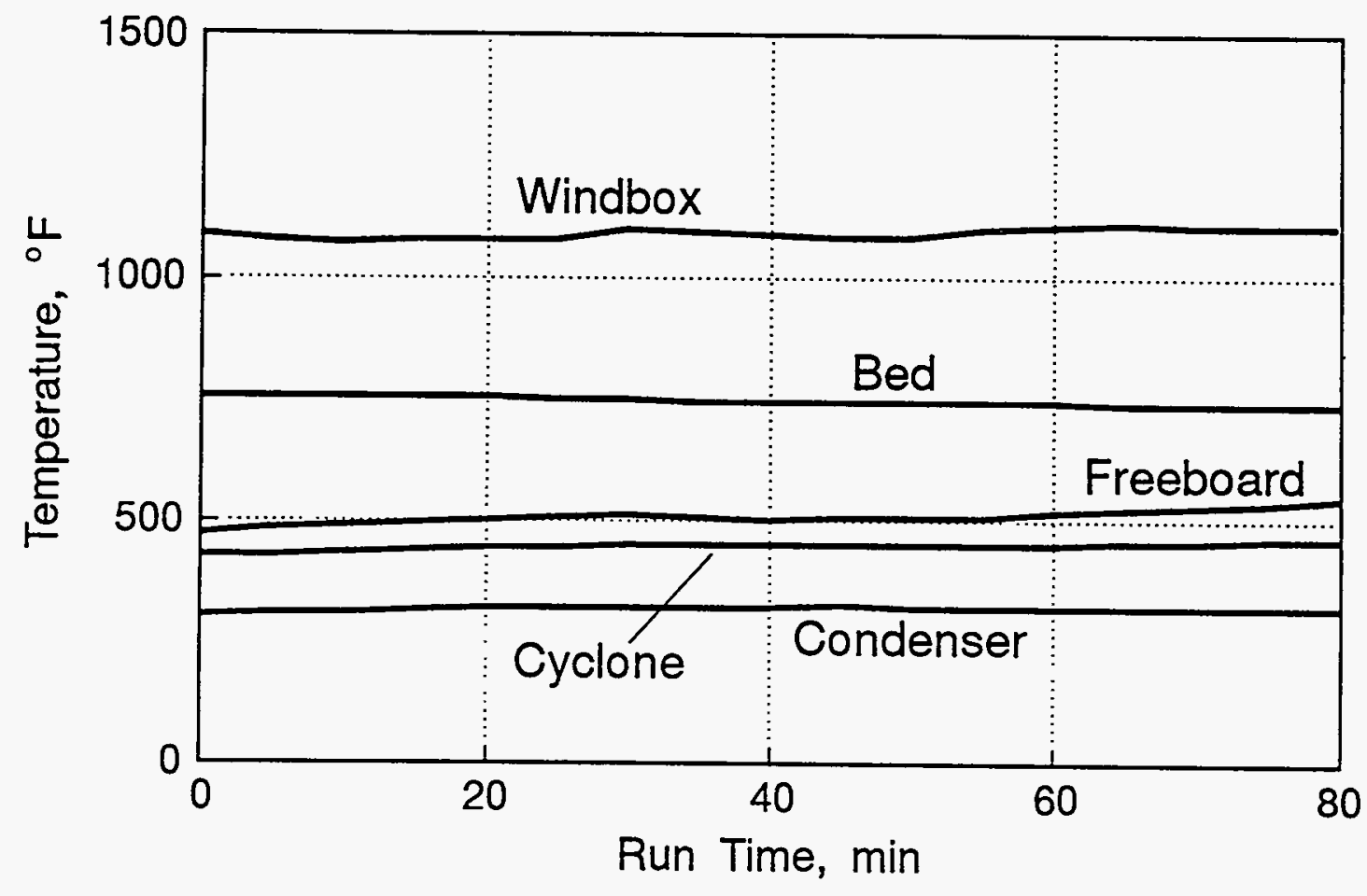

Figure 8. Temperature Logs for Test Number 2 


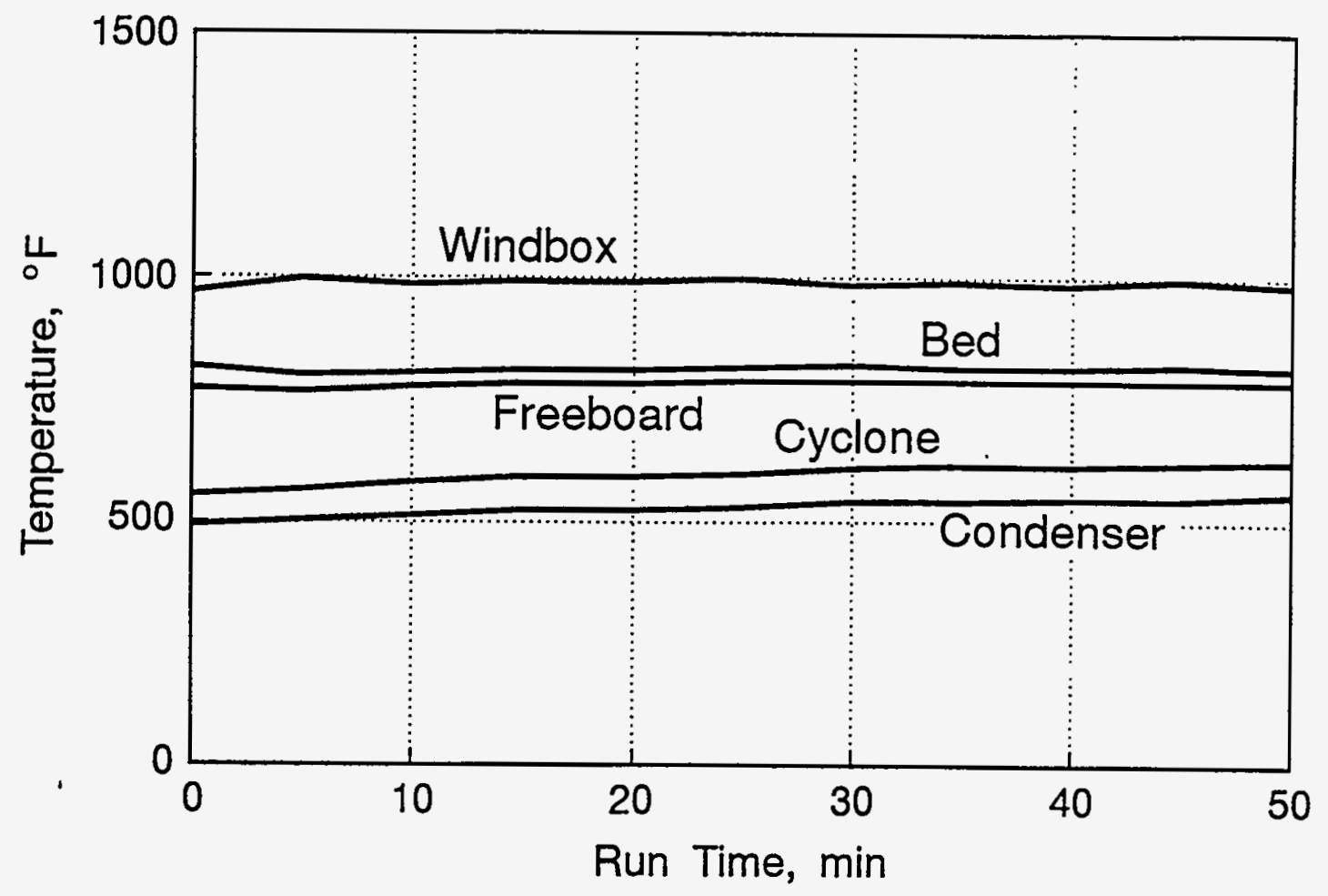

Figure 9. Temperature Logs for Test Number 3

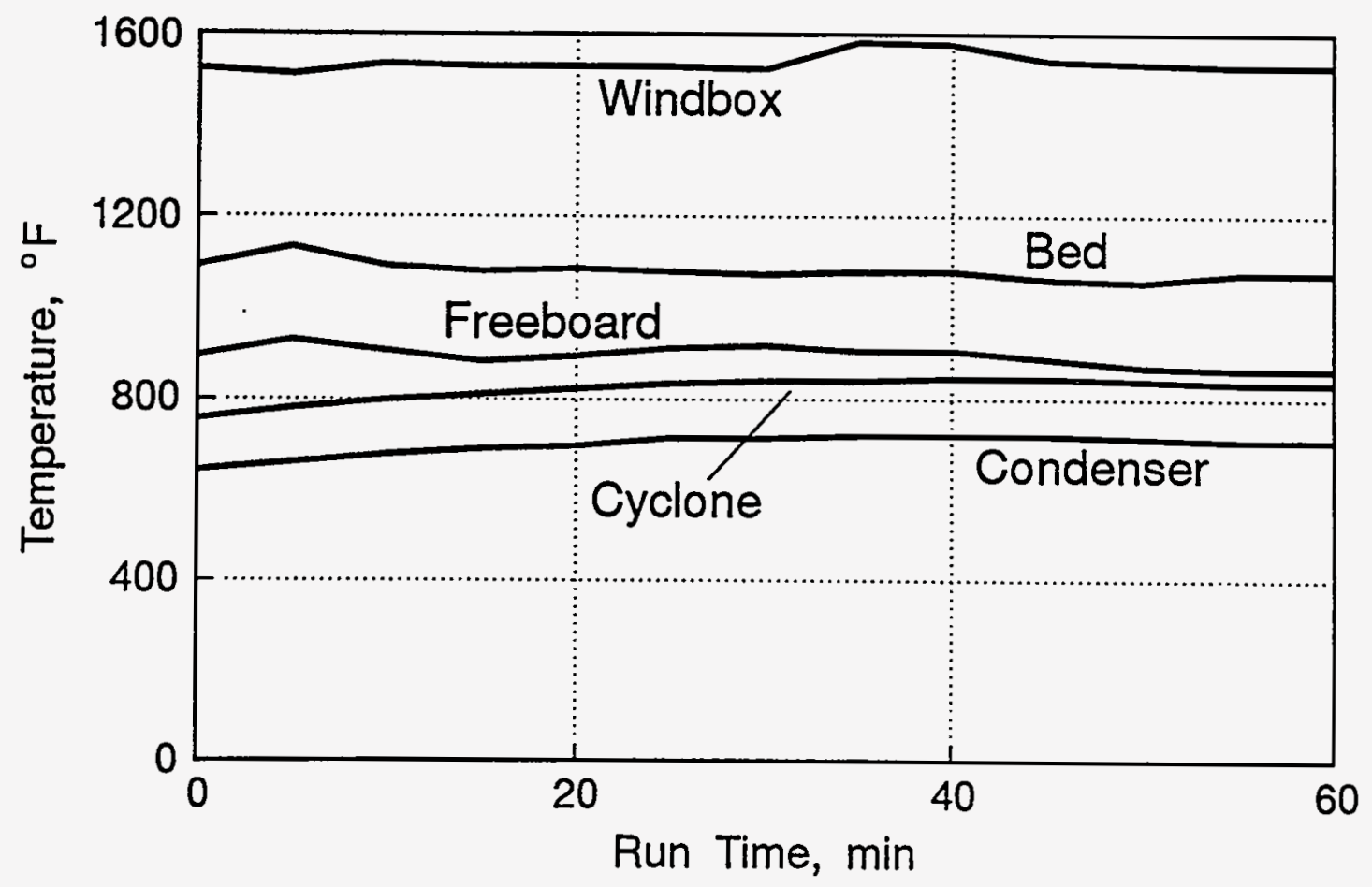

Figure 10. Temperature Logs for Test Number 4 


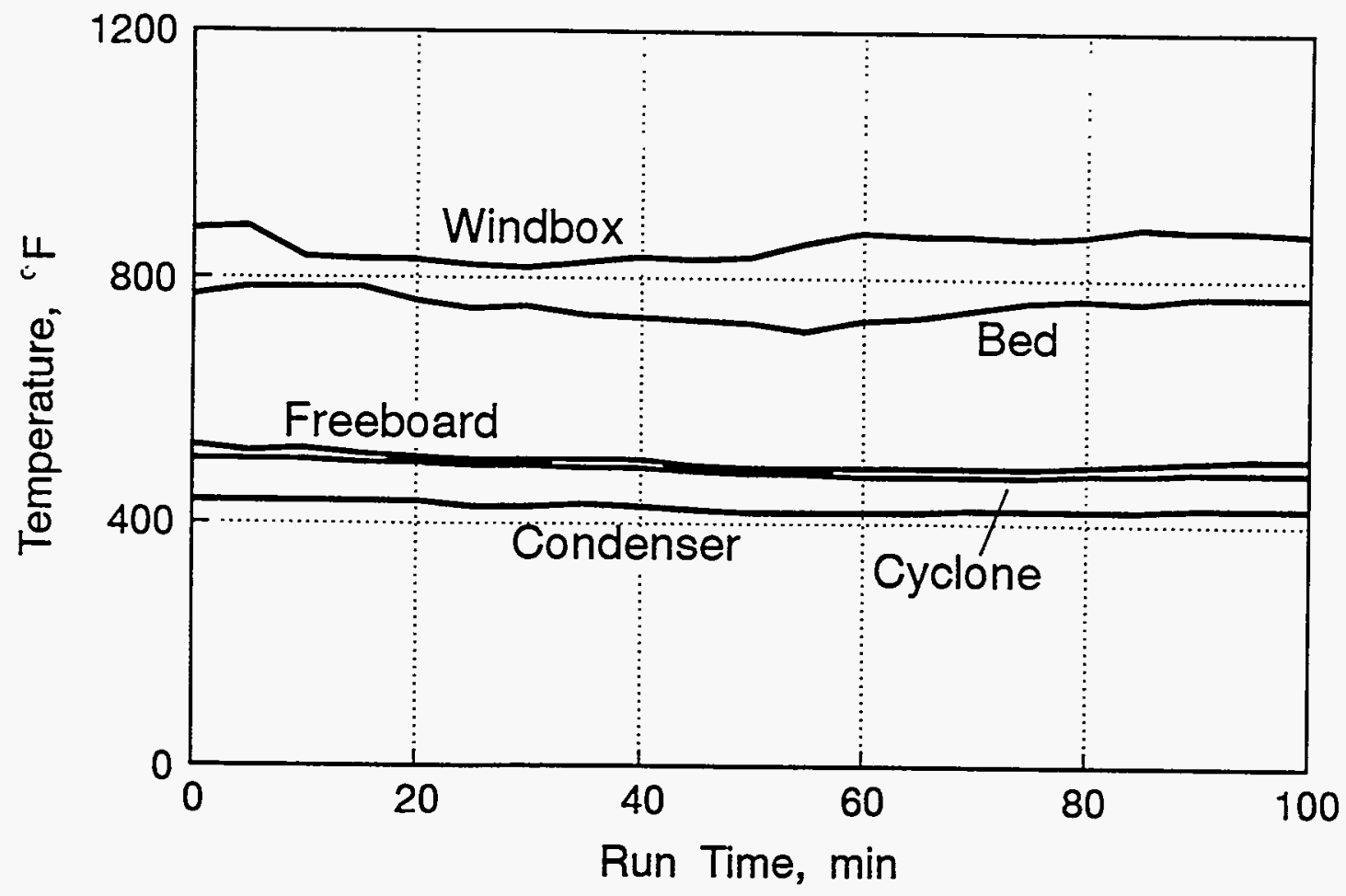

Figure 11. Temperature Logs for Test Number 5

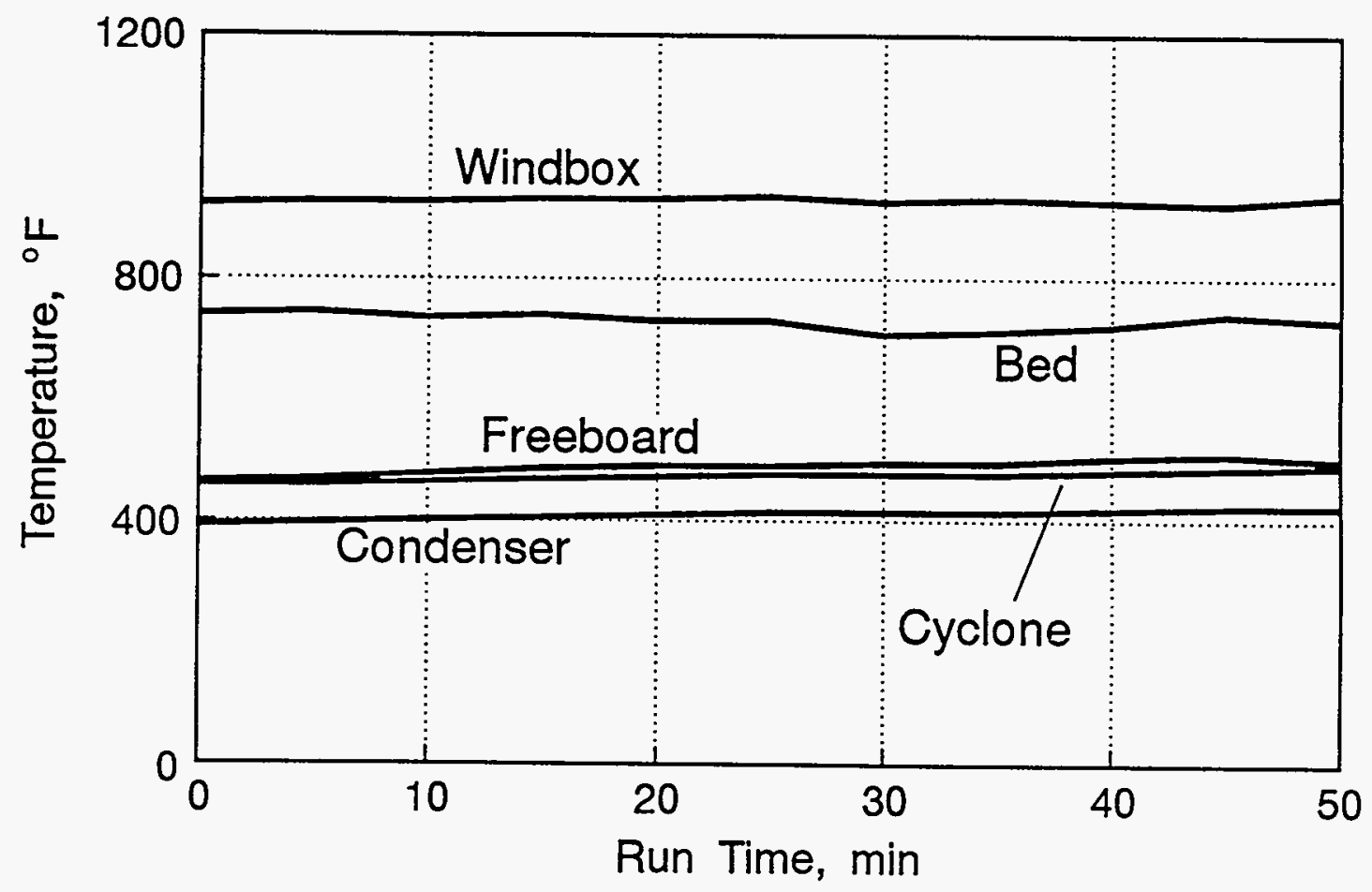

Figure 12. Temperature Logs for Test Number 6 


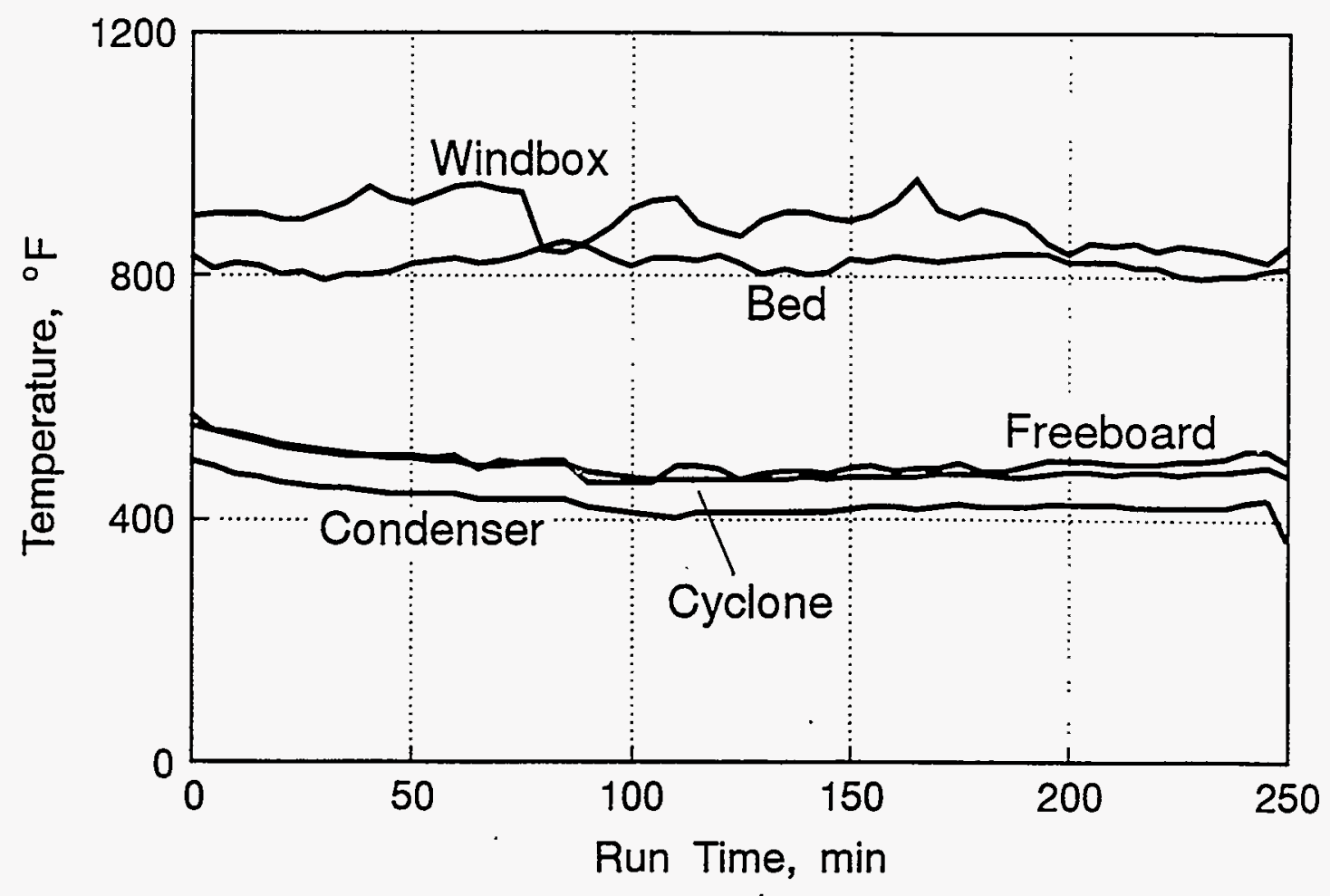

Figure 13. Temperature Logs for Test Number 7

\section{Oil Recovery}

Various spent solids samples collected during the tests were analyzed for oil and water to establish organic recovery. Data are compiled in Table 2. The table lists the oil and water content of the spent bed materials and those of the solids discharged by the primary cyclones. Oil recovery is then computed based on the residual oil and "coke" content in the spent bed material. Secondary cyclone catches during the tests were too small to be analyzed and hence are not included in this analysis.

Data displayed in Table 2 can be categorized into two sets, (1) tests (Tests $2,3,5-7)$ employing a bed temperatures in the oil recovery regime, (i.e., less than $850^{\circ} \mathrm{F}\left[454^{\circ} \mathrm{C}\right]$ ), and (2) tests (Tests 1 and 4) employing a bed temperature in the gasification regime (bed temperature $>1000^{\circ} \mathrm{F}\left[538^{\circ} \mathrm{C}\right]$ ). Optimum oil recovery regime appears to be when the bed temperature is maintained at about $750^{\circ} \mathrm{F}\left(\sim 399^{\circ} \mathrm{C}\right)$. Note that the windbox temperature is dictated by the feed rate, in that higher the feed rate, the higher the windbox temperature. However, the temperature difference between the windbox and the bed can not be very large because of the onset of coking and gasification 
reactions in the material in contact with the distributor. Based on the solids analyses, it is deduced that $75+\%$ oil recoveries are indeed possible. This is consistent with the Phase 1 results obtained in a bench-scale reactor. Test 4 results indicate that under severe processing conditions, organic materials can be almost completely removed from oily feeds. However, based on bench-scale tests conducted during Phase 1 , the recovered product under these conditions is not a liquid but gas.

Table 2. Summary of Test Conditions and Results

\begin{tabular}{|c|c|c|c|c|c|c|}
\hline \multicolumn{3}{|c|}{ Test Conditions (F) } & \multicolumn{3}{|c|}{ Oil Content (wt \%)* } & \multirow[b]{2}{*}{ Recovery (\%) } \\
\hline No. & Bed & Windbox & Feed & Bed & Cyclone & \\
\hline 1 & 1084 & 1284 & $4.67(0.39)$ & $2.12(0.99)$ & 0.00 & 41.8 \\
\hline 2 & 747 & 1093 & $1.51(0.42)$ & $0.01(0.35)$ & 3.64 & 99.9 \\
\hline 3 & 816 & 991 & $5.02(0.32)$ & $0.49(1.10)$ & 0.21 & 74.7 \\
\hline 4 & 1079 & 1536 & $10.39(0.65)$ & $0.02(0.56)$ & 4.48 & 99.8 \\
\hline 5 & 757 & 856 & $6.97(0.40)$ & $0.26(1.34)$ & 6.06 & 82.8 \\
\hline 6 & 732 & 927 & $7.71(0.91)$ & $3.61(2.02)$ & 11.92 & 38.8 \\
\hline 7 & 822 & 893 & $6.57(0.41)$ & $2.99(1.72)$ & 0.00 & 34.6 \\
\hline
\end{tabular}

* Values in parentheses reflect "coke", organic matter which could not be extracted in the Soxhlet extraction process. 


\section{SUMMARY AND CONCLUSIONS}

A two-phased experimental test program was undertaken to develop an oil recovery process applicable to near-surface, oil-bearing deposits. Recovery of oil from such deposits by conventional production technologies is either difficult or uneconomical. However, mining and surface processing can be economical because a larger fraction of the oil-in-place is recovered.

The reservoir selected for the Phase 1 bench-scale testing and development of the process, and for the subsequent Phase 2 field demonstration was the Sherard Dome reservoir located in the Big Horn Basin of Wyoming. Phase 1 testing and results have been previously published.

Based on the results from Phase 1 testing, the process selected for field demonstration was based on the fluidized-bed technology. The main advantages of the selected technology were the process scale-up considerations and the need to achieve high heating rates and short residence times, both were demonstrated to affect the efficiency of oil recovery. Fluidized-bed technology also offers an added advantage in that higher throughput is possible in a relatively small reactor.

A plant capable of processing 100 tons per day of feed material was designed, fabricated, and assembled at the Sherard Dome. The plant was operated for a period of about 1 month. Several problems were experienced. The major issues pertained to the lower than expected, and variable oil content of the feed. These in turn had an adverse impact on the performance of product recovery components, and on process control. Nevertheless, several tests were performed and the plant processed sufficient quantities of the low grade feed to warrant the following conclusions.

1. A fluidized-bed reactor can be used to recover oil from near-surface oil deposits, provided

(a) the feed does not contain rocks, if rocks do exist then front end preparation equipment should be designed for separation and or crushing, and 
(b) the oil content of the feed is consistent and high enough to economically offset carbon losses to coking and gasification reactions, and losses due to vapor pressure considerations.

2. Based on the analyses of the spent bed material, $75+\%$ oil recoveries can be achieved by using this technology. Optimum bed temperature for oil recovery appears to be in the $750-850^{\circ} \mathrm{F}\left(399-454^{\circ} \mathrm{C}\right)$ temperature range.

3. The technology can also be used as a remediation technology, where by employing more severe processing conditions (bed temperature $>1050^{\circ} \mathrm{F}$ $\left.\left[566^{\circ} \mathrm{C}\right]\right)$, nearly all of the organic material can be removed from organic contaminated soils. Under these operating conditions, the organic materials are "gasified" and hence can either be incinerated at the flare or incinerated to provide heat for the process. 


\section{ACKNOWLEDGEMENT}

The authors express appreciation to the U.S. Department of Energy for funding of this work under Cooperative Agreement Number DE-FC21-86MC11076 and to the Wyoming Department of Commerce, Economic Development and Stabilization Department.

\section{DISCLAIMER}

Mention of specific brand names or models of equipment is for information only and does not imply endorsement of any particular brand. 


\section{REFERENCES}

Satchwell, R.M., L.A. Johnson Jr., and V.K. Sethi, 1993, Assessment, Design and Testing of Oil Recovery and Processing Technologies for NearSurface Reserves. Laramie, WY, WRI-93-R029.

Chuman, R.W., and J.C. Paine, 1988, Sherard Dome Project, Washakie County, Wyoming: Unpublished maps and reports prepared for Kaycee Oil. 